\title{
Circulating power: humanitarian logistics, militarism and the United Arab Emirates
}

\author{
Rafeef Ziadah
}

\begin{abstract}
While critical authors have interrogated the roots of business logistics, this paper extends the analysis and contributes to a larger critique of the cohering field of Humanitarian Logistics (HL), noting the overlap in the logistical cartographies of militarism and humanitarianism. The focus is on the UAE's expanding logistics space into the Horn of Africa and the production of specialised HL zones like Dubai International Humanitarian City (DIHC). The article makes three core arguments. First, a logistics lens enables us to expand the study of aid beyond immediate conflict zones, into more distant spaces often constructed as 'stable'. Second, the placement of logistics at the core of aid delivery has been a key mechanism for inserting market imperatives into humanitarian activities. Third, this gives countries outside the advanced core, such as the UAE, power to leverage and expand their logistics space for multiple purposes, in war making, aid, and commercial activities.
\end{abstract}

Keywords: humanitarian logistics, United Arab Emirates, Dubai, Dubai International Humanitarian City, Horn of Africa, Yemen

\section{Introduction}

Over the past decade, a wide-ranging critical academic literature has emerged around the notion of 'humanitarianism' and the modalities of humanitarian intervention. As part of this work, scholars across a diverse range of fields have pointed to the intersection of neoliberalism, securitisation and humanitarian practice (Duffield 2001; Fassin 2011; Calhoun et al. 2010; Chandler 2001), arguing that the practice of humanitarian organisations has tended to reinforce a 'bunkerisation' of aid delivery, with an emphasis on remote technologies and a distancing from local populations. Such accounts have drawn out the profoundly contradictory nature of humanitarianism, including its imbrication with past and present forms of liberal and imperial governance (Skinner and Lester 2012; Fassin and 
Pandolfi 2010; Reid-Henry 2014), and the overlap between humanitarian discourse and policies with key aspects of counterinsurgency warfare (Bryan 2015; Khalili 2012; Weizman 2011; McCormack and Gilbert 2018). These critical contributions have been essential to unpacking the underlying dynamics of humanitarian intervention in a world marked by unprecedented levels of cross-border violence and numerous protracted conflicts that are transnational in form.

Nonetheless, despite the transnational character of both conflict and humanitarian response, much of the literature has implicitly adopted a kind of 'methodological nationalism' - where the focus is placed on immediate conflict zones located within narrowly defined national spaces. The spatiality of war, as Graham (Graham 2009) and Gregory (Gregory 2011) insist, has spread far beyond defined frontlines - yet this shift has not been adequately theorised in the critical work on humanitarianism. In what follows, I seek to highlight a fundamental component to this transnational shift: the question of logistics and the increasing overlap in the cross-border spatial cartographies of military operations, humanitarian aid delivery, and private logistics firms. The "logistics revolution", as Attewell perceptively notes, holds a "central yet largely unacknowledged role in shaping humanitarian and development practice" (Attewell 2018: 722). How aid travels to where it is to be delivered - who controls the logistical nodes and supply chains, how these intersect with activities of military and private actors, and the resultant reorganisation of the geographies of power in conflict-affected regions - are essential but understudied lacunae in the scholarly work on humanitarianism.

Framed by these theoretical concerns, I examine the intersection of logistics and humanitarianism through a study of a much-neglected humanitarian (and military) actor: the United Arab Emirates (UAE). While most work on humanitarianism looks at the activities of 
states, militaries and private firms located in the Global North, the rise of new humanitarian actors in the Global South is a striking feature of the contemporary humanitarian landscape. The UAE is now the world's largest aid donor and plays a major role in the delivery of humanitarian assistance across the globe. Much of this relief assistance is coordinated through Dubai International Humanitarian City (DIHC), the largest humanitarian logistics hub in the world, which hosts UN organisations, non-governmental organisations, and commercial firms involved in the management, storage, and global distribution of aid. These humanitarian flows are underpinned by the UAE's sophisticated logistics infrastructure, including a panoply of roads, maritime, and air ports; warehousing and processing zones; and an array of logistics services provided by commercial UAE-based firms that rank among the biggest of their kind globally. At the same time, the UAE is rapidly projecting its own military power across its immediate neighbourhood; most clearly through its intervention in Yemen, but also within a wider zone encompassing the Red Sea, East Africa, and Indian Ocean, now one of the most militarised maritime spaces internationally (Jones 2012). Nonetheless, while devastating conflict and mass displacement has concentrated attention on individual states like Syria, Yemen, Libya, Iraq and their immediate borders, analysis of the UAE's critical role as a major humanitarian logistics hub has been absent. A methodological focus on narrow conflict zones - essential as this may be to understanding the operations and limitations of humanitarian organisations - has helped to obfuscate the emerging position of more 'distant' and 'stable' states like the UAE in commercial, military and humanitarian logistics.

Utilising the UAE's enlarged role as a major humanitarian actor as a window into a broader analysis, this article makes three core arguments. First, a logistics lens enables us to expand the study of aid beyond immediate conflict zones, into more distant spaces often constructed and promoted as 'stable', but which are nonetheless deeply entangled in the ongoing reality of 
conflict. Second, the placement of logistics at the core of aid delivery has been a key mechanism for inserting a wide range of market imperatives into humanitarian activities, including concepts of 'supply chain efficiency', privatisation, and a dependency on the racialised labour regimes found in the commercial logistics sector. Third, this gives countries outside the advanced core, such as the UAE, power to leverage and expand their logistics space for multiple purposes, in war making, aid, and commercial activities. The UAE's logistics space is co-constituted at the intersection of these overlapping interests; the country is expanding territorially and integrating humanitarian logistics as a key element of this projection of power - bolstered by a branding campaign that presents the UAE as a stable commercial hub and 'giving nation'.

In making these arguments, my analysis moves between multiple spatial scales: local (Dubai International Humanitarian City and the Emirate of Dubai as the main logistics hub), national (the UAE), and regional (the wider Middle East and Indian Ocean space). I bring into dialogue and extend three sets of critical literature: first, the critical literature on logistics space (Cowen 2014; Sekula and Burch 2011; Danyluk 2017; Neilson 2012), which has done much to expand our understanding of the underlying commercial and military infrastructures of contemporary capitalism, but has largely ignored the issue of humanitarian logistics. Second, the rich literature that has attended to the changing nature of humanitarianism, including the production of "remote" and "bunkerised" spaces of aid provision (Duffield 2012; Smirl 2015), and finally scholarship on forms of neoliberal urbanisation in the UAE, which emphasises the significance of linked free zones, well-developed multi-modal transport infrastructure, and a loose regulatory environment in shaping the nature of the UAE's urban spaces, (Kanna 2011; Ramos 2010; Buckley 2013; Elsheshtawy 2010). Coming from a variety of disciplines and points of theoretical departure, these literatures help to form a 
multidisciplinary perspective, providing further insight into the UAE's state-sponsored attempts to consolidate its logistical capacities (commercial, military and humanitarian) and to project its power over a pivotal geo-economic space.

I begin with a literature review that draws together this different scholarly work and presents a critique of the cohering mainstream discipline of Humanitarian Logistics (HL). I then turn to the overlapping cartographies of the UAE's military, commercial and humanitarian logistics space with a focus on its expansion into the Horn of Africa and Yemen as the most direct and prolonged site of military intervention. Finally, I attend to the emergence of DIHC as a core element of the UAE's logistical space, a process underpinned by the branding of the UAE as liberal, stable and 'giving', but which ultimately serves to reinforce the country's wider military and commercial ambitions. The analysis draws on site visits to Jebel Ali Port, Jebel Ali Free Zone and DIHC, as well as semi-structured interviews with humanitarian staff in the UAE. I have also reviewed government, NGO, and media reports (in Arabic and English) on the UAE’s humanitarian work between 2013 and 2018.

\section{Deciphering Humanitarian Logistics}

Analysis of the 'logistics revolution' is typically framed by the changes to late $20^{\text {th }}$ century capitalism and the essential role of intermodal mega-transport infrastructures and connected logistics corridors in shaping the spatiality of global commodity circulation (Danyluk 2017; Bonacich and Wilson 2008; Mezzadra and Neilson 2015). Scholars have pointed to the set of technoscientific innovations, such as the container and computerised modelling, which helped to standardise and reduce circulation time (Levinson 2008), integrating regions differentially into what Tsing has termed 'supply chain capitalism' (Tsing 2009). Within this process, it is 
important to differentiate between 'business logistics' - what Cowen has describes as "the management of circulation across the entire system of production and distribution" - and the wider 'logistics space' that undergirds and enables this circulation, a “network space, constituted by infrastructures, information, goods, and people, [that] is dedicated to flows.” (Cowen 2014: 8).

Precisely because logistics is grounded in the attempt to speed up of the turnover time of capital, labour presents a particular significant potential challenge due to the ability of workers to disrupt flows (Fox e e\$oæ017; Toscano 2014; Neilson 2012). For this reason, in historicising the development of the logistics revolution, authors have paid particular attention to the intrinsic violence of hyper-securitised supply chains, counterposing such security with the insecure labour that is often involved in the 'efficient' movement of commodities (Chua 2018; Kanngieser 2013). Moreover, challenging the mainstream construction of business logistics as a technical applied science, others have traced the roots of business logistics within the field of military logistics (Chung 2019), noting that the "military art of moving soldiers and supplies to the front" has become a "business science" that animates all aspects of war-making (Cowen 2014, 4). Although forged in earlier military contexts, the US-led War on Terror, increased the centrality of privatised logistics to modern warfare (Moore 2017; Abrahamsen and Leander 2015). Logistics corporations developed into significant components of military missions, often contracted to move supplies and take on feeding and housing troops. This growing scholarly interest in the operations of logistics spaces has yielded insightful studies on the entanglements of military and commercial logistics. 
The conception of logistics "as a calculative logic and spatial practice of circulation that is at the fore of the reorganization of capitalism and war” (Chua et al. 2018) forms a central framing element for the analysis that follows. Nonetheless, while critical authors of the logistics revolution have examined the roots of business logistics in military violence, there is a major gap regarding its role in humanitarian engagements. While much work has focused on the violence of humanitarian regimes and their role in population management (Duffield 2012; Fassin and Pandolfi n.d.; Seshadri 2008), the day-to-day logistics and material circulation of supplies that make humanitarian aid possible has received little attention. This gap contrasts with mainstream humanitarian practice, which now elevates supply chain efficiency, return on donor investment and privatisation of service delivery, as key drivers of humanitarian action. Humanitarian aid delivery has increasingly become a set of technical business transactions, broken into component parts, and distributed into complex geographical arrangements. Indeed, this shift is captured in the emerging field of Humanitarian Logistics (HL), a technoscientific discipline (now with its own academic journal) that is widely defined along the following lines:

"the process of planning, implementing and controlling the efficient, cost effective flow and storage of goods and materials as well as related information from the point of origin to the point of consumption for the purpose of alleviating the suffering of vulnerable people. The function encompasses a range of activities, including preparedness, planning, procurement, transport, warehousing, tracking and tracing, customs and clearance” (Thomas and Kopczak; 2005: 4)

The newly cohering field of HL as a discreet field of study and practice speaks to the deepening incorporation of humanitarian aid into supply chain capitalism. This process is often dated to the 2004 Indian Ocean Tsunami and the ensuing critique of a lack of logistical preparation for disaster relief. Yet, attempts at clustering HL functions were used as early as the 1990s. Two crucial changes based on the Humanitarian Reform Programme gave logistics a more fundamental role: first, the establishment of topical clusters, one of which was the 
Logistics Cluster in 2010; and two, crucially for this analysis, the formation of regional multiagency logistical hubs for warehousing and pre-positioning supplies. ${ }^{1}$ What is new then is not the relevance of logistics to aid delivery, but rather the scale in which it has moved from being a 'back room activity' to being central to the operations of a supply-chain humanitarianism. Accompanying this shift is the adoption of the key tenets of business logistics: a reliance on remote technologies, 'Just in Time' management techniques, models of vertical integration, prepositioned warehouses and quantitative cost modelling - all of which have been more or less fully adopted by the humanitarian sector (Balcik and Beamon 2008; Kovács and Spens 2011; Van Wassenhove 2006). Additionally, HL functions have been increasingly valorised by aid agencies, with logisticians elevated to the top ranks of humanitarian organisations. A growing number of university degrees, often attached to business departments, produce a steady stream of graduates trained in such humanitarian supply chain management.

Within the mainstream approach to HL there is an open espousal of the benefits of collaboration between humanitarian agencies and the commercial sector, often structured as long-term alliances or shorter-term initiatives that prioritise return on donor investment. ${ }^{2}$ Basic assumptions that HL lags behind the commercial sector and would do well to learn and adapt its policies permeate the literature (Whiting and Ayala Roussat, and Jahre 2008). Advocates of such collaborations posture that these partnerships can become learning laboratories for both parties (Tomasini and Van Wassenhove 2009), and take pains to trace parallels between the performance indicators of business logistics and HL (Van der Laan, De Brito, and Vergunst 2009; Gray and Oloruntoba 2009). This in turn helps to construct business logistics as a neutral science of circulation through which logistics firms 
learn to act across multiple spaces, equally marketing their expertise to militaries and humanitarian organisations.

At stake, however, is not simply the privatisation of logistics functions or the internalisation of market imperatives within humanitarian action. Fundamentally, the logic of supply-chain humanitarianism helps to displace the risk of aid delivery onto local actors, constructing populations on the receiving end as customers to be 'serviced'. It is local actors who endure the largest risks of the material delivery of aid, while those in more 'remote', ostensibly 'stable' external zones can be shielded from direct impact. In this sense, the prioritisation of HL echoes Duffield's observations around the wider shift in forms of humanitarian aid delivery: “increasing recourse to arm’s length remote management and risk-avoidance when it comes to international terrestrial deployments in the global South” (Duffield 2016, 148). Essential to understanding this phenomenon of 'remoteness', however, is its infrastructural architecture - a transnational network of logistics spaces, which in turn, acts to intensify the spatial division between logisticians, managing the supply chain at a safe distance, and those aid workers directly in the field.

Moreover, largely overlooked in the critical literature on humanitarianism, is the day-to-day labour of logistics that allows for humanitarian supplies to circulate in the first place. This type of labour is often written out of the narrative of humanitarian operations, although aid delivery is highly dependent on this very material movement of emergency supplies. As Attewell (Attewell 2018, 722) points out, "humanitarian and development actors have relied upon the labour that is performed in network spaces such as docks, warehouses, highways, and ports to intervene in theatres of conflict and emergency." The overlap between commercial, military and humanitarian supply-chains has meant that $\mathrm{HL}$ is 
dependent on the same racialised labour regimes that characterise supply-chain capitalism. In other words, a logistical lens allows us to trace the ways in which humanitarian interventions, ostensibly planned to support populations facing war and/or disaster, are fundamentally mediated by remote infrastructures that incorporate various forms of violence.

In short, no matter how technical and apolitical humanitarian supply-chain management presents itself to be, it remains underpinned by power relations between those managing the "chain" at a distance, those doing the manual labour of logistics, as well as those on the receiving end. At the same time, the prioritisation of HL has generated a shift in the spatiality of these power relations - elevating regional actors that can take advantage of their insertion in global trade and logistics networks, pre-existing infrastructures, loose regulatory environments, and highly 'flexible' racialised, labour regimes. The degree to which such regional actors are able to market themselves as 'islands of stability' and 'efficiency' in otherwise chaotic neighbourhoods serves to strengthen their comparative advantage in HL (a discursive framing that often codes for authoritarian stability and lack of labour rights). In turn, as these new HL actors become increasingly central to the military-humanitarian nexus, their regional footprint and wider power projection is extended and fortified. In this manner, a deeper investigation of $\mathrm{HL}$ and their associated logistics spaces helps elucidate the new geographies of power emerging in zones of war and conflict.

\section{The Commercial, Military and Humanitarian Nexus of the UAE Logistics Space}

The United Arab Emirates presents an excellent case study through which to investigate the intersection of war-making, humanitarianism, and logistics. Throughout much of the late $19^{\text {th }}$ and early $20^{\text {th }}$ century, the country formed an important node within the wider circulatory 
networks of British colonialism in the Gulf region (Heard-Bey 1982; Zahlan 2016). Following independence in 1971, rapid urbanisation - coupled with the development of largescale logistics infrastructure, notably Dubai's Jebel Ali Port (constructed in 1979) - were critical to patterns of state and class formation in the UAE, as well as the demarcation of political power between the seven emirates that make up the country (Davis, Mike 2006; Kanna 2011; Molavi 2005; Davidson 2008; Elsheshtawy 2010)(Ramos 2010; Ziadah 2018). Today, the UAE can be described as a 'nexus state' (Henderson 2017), through which a networked logistics space of mega infrastructures (maritime ports and airports), free trade zones, logistics cities, corporatised port operators, and private logistics firms, serve to connect and mediate internationalised supply chains across the globe.

The epicentre of this logistics space is the Emirate of Dubai, where the state-owned Dubai Ports World (DP World) has joined the ranks of a small number of corporate Global Network Terminal Operators (GNTs) that now dominate the global maritime industry (Ziadah 2017). DP World's flagship port, Jebel Ali, is the world's largest engineered harbour and largest container port between Rotterdam and Singapore. In addition, the company now controls a network of more than 70 terminals around the world following aggressive international expansion over recent years. Nonetheless, while Dubai remains the pre-eminent logistics and trade hub in the UAE, other neighbouring Emirates are attempting to replicate its model. Abu Dhabi continues to expand Khalifa Port, and Sharjah hosts the important Khor Fakan port, a container transhipment port strategically located on the Indian Ocean adjacent to the Straits of Hormuz. All of these ports are typically anchored within free zones that link to road and air infrastructure and also provide warehousing, commercial, and office facilities. Such zones are governed through highly liberal trade and investment regulations designed to attract foreign 
and local corporations, including incentives such as $100 \%$ foreign ownership and $0 \%$ corporate tax for 50 years (a concession that is renewable).

But beyond the loose regulatory environment underpinning the development of UAE free zones and transport infrastructure, it is critical to consider the overlap between commercial and military functions within these logistics spaces. The UAE is pivotal to a wider US-led regional order in the Gulf (Jones 2012) in an alliance that has been described by former commander of all US troops in the Middle East, Anthony Zinni, as "the strongest relationship that the United States has in the Arab world today” (Chandrasekaran 2014). The UAE's maritime and airports form an important strategic asset in this relationship. A US-UAE Defence Cooperation Agreement (DCA) gives the US military almost unfettered use of the UAE’s logistical infrastructure and American military personnel are frequently stationed at the ports of Fujairah, Jebel Ali, and other locations throughout the country (Katzman 2013). Indeed, Jebel Ali is the US navy’s “busiest overseas port of call” (Chandrasekaran 2014), with a deep-water harbour able to accommodate larger US military vessels.

This centrality of the UAE's networked logistics space to the projection of western military power is closely entwined with the growth of a flourishing private logistics sector. Dubai's close proximity to Iraq and Afghanistan helped to expand both the number of private military contracting companies based there, as well as logistics firms that provide services to the US military. Indeed, many local logistics firms registered in the UAE began their life as contractors for the US military. Agility, a leading Kuwaiti-owned, but Dubai registered company, has held multiple contracts with the US military (Reuters 2017). Al Futtaim, owned by a leading UAE domestic capital group, advertises its credential as "prime contractors to NATO forces in conflict zones” (Al-Futtaim Logistics, n.d.). Dubai-based logistics firms have 
also been key to the provision of logistical labour to the US military, with Moore (2017) noting that such firms "tapped recruiting brokers and agencies in countries like India, the Philippines, Nepal, and Sri Lanka to amass the pool of labourers needed to fulfil their [the US’] growing contractual obligations in Iraq.” (Moore 2017, 11) (Moore 2017) This specialisation in the recruitment of logistical labour maps neatly onto the UAE's longestablished labour regime - a highly hierarchical, ethnoracial labour regime in which trade unions and public protests are banned. ${ }^{3}$

Alongside these long-standing linkages with the US military, the growth of the UAE logistics space increasingly underpins the expansion of the UAE's own regional footprint. This is a relatively new development that began in the 1990s, but really accelerated through the 2000s in the aftermath of the 2011 Arab uprisings. Alongside the emergence of new centres of global accumulation in countries such as China, the UAE (and other Gulf states) have sought to position themselves within a fast-changing international order. One way in which this has been expressed is through the UAE's development of new commercial maritime ports and military bases located outside the state's territory. Particularly prominent in this expansion are the coastal areas of the Arabian Peninsula, Indian Ocean, and Red Sea - a critical region whose shipping lanes are expected to constitute an important crossroads of global trade in the coming years.

The UAE's participation in the Saudi-led attack on Yemen ${ }^{4}$ - involving more than 5500 Emirati troops in ground, naval, and air operations - provides striking illustration of this strategy. As part of this intervention in Yemen, there has been a fairly distinct territorial demarcation between Saudi Arabia, concentrated in the northern areas of Yemen, and the UAE, which has largely focused on building alliances with tribal and political forces in the 
southern areas of the country. Through these alliances and its direct military presence in Yemen, the UAE has taken control of three critical Yemeni ports —Mukalla, Aden and Mokha—as well as an oil export terminal located in the eastern coastal city of al-Shihr. As a consequence, the UAE now holds effective power over the flow of goods into much of Southern Yemen.

Utilising this territorial control, focused especially on coastal towns, the UAE is attempting to block potential competitors and engineer a new, expanded logistics space that links key ports in the UAE (such as Jebel Ali) with Yemeni ports now under UAE domination. Within this endeavour, the language of humanitarianism - and the power to control the logistics of humanitarian flows - has become central. This can be seen, for example, in the Emirati emulation of western military strategies to 'win hearts and minds' through the active distribution of aid in Yemeni port towns under UAE control (usually accompanied by reporters from the state-owned Emirates News Agency). Likewise, following negative publicity from the all-out closure of Yemeni ports by the UAE and Saudi Arabia in November 2017, the UAE increased its humanitarian package to Yemen, making it the largest recipient of all UAE foreign aid globally. This aid, however, was predicated upon establishing direct shipping lanes between the UAE and Yemen, and largely focused on rebuilding transport infrastructure in the various ports noted above. By framing the reconstruction of Yemeni ports and their tighter linkages to the UAE as 'aid', the UAE is set to powerfully shape postconflict trajectories in Yemen for years to come.

This intersection of military, commercial, and humanitarian logistics needs to be situated in the UAE's ambitions across a wider strategic zone encompassing the Indian Ocean, Arabian Peninsula, and Red Sea. ${ }^{5}$ In this area, the spatial restructuring of the UAE's war-making 
capacities and humanitarian networks are elaborated in dual-use logistics infrastructures that aim - beyond the Yemeni ports noted above - to control circulation across (and through) coastal areas of Africa including Somaliland, Eritrea, Sudan, Djibouti, South Sudan, Somalia, and Egypt. ${ }^{6}$ In Somaliland, for example, DP World signed a 30-year concession in May 2016 for the port of Berbera, which included the construction of a logistics park and free trade zone. In 2018, the UAE announced it was also building a military base adjacent to the DP World facilities, with the former Somaliland ambassador to the UAE confirming: "the U.A.E. has become the hub of the whole region in terms of trade... [it] cannot do that if it does not secure the lifeline of trade” (Manek 2018). The Eritrean deep-water port of Assab, by contrast, was provided to the UAE military on a 30-year lease in 2015; it has since become a pivotal staging post for UAE and Saudi military attacks on Yemen as well as a transhipment hub for UAE humanitarian aid to Mukalla (a UAE-controlled port town on Yemen's southern coast). In late 2018, DP World CEO, Sultan Ahmed bin Sulayem, commented that the firm saw "a major role" for Eritrea in its regional expansion plans, noting that "we believe that the way we should look at the Horn of Africa is not at Eritrea alone, but add to the equation South Sudan, other parts of Sudan, and Eritrea's needs, and then the Ethiopian population.” (Manek 2018)

These patterns confirm the close imbrication of the UAE's humanitarian logistics networks with the country's military and commercial ambitions. While the growth of UAE logistics infrastructure has a long connection with militarism and the US presence in the Gulf, the centrality of HL to contemporary conflict and crisis response mechanisms means that the UAE's war-making capacities exist in a mutually-reinforcing relationship with the country's humanitarian efforts. In this manner, HL operates alongside and helps to strengthen the UAE's wider regional projection of power. Rather than reading military action, development 
aid, and humanitarian engagements as separate spheres, they are better understood as coconstitutive elements of a singular strategy, tied together through the UAE logistics space - a space that is fully transnational in character, extending from the ports, free zones, and warehouses of the UAE, through to the devastated port towns of Yemen and the UAE military bases in the Horn of Africa.

The UAE and Humanitarian Logistics: The Case of DIHC

These core features of the UAE's expanding logistics space are further bolstered by the country’s rapid emergence as a major humanitarian actor. At one level this is reflected in high levels of foreign assistance, which the UAE government claimed reached $\$ 6.05$ billion in 2016 (including both development and humanitarian aid), making the country the largest international donor in the world (United Arab Emirates Ministry of Foreign Affairs \& International Cooperation 2017). According to latest OECD reported data, UAE total net overseas development assistance reached $\$ 4.4$ billion in 2015 . This aid is disbursed through a web of national agencies (the Abu Dhabi Development Fund being the largest), Red Crescent societies, and over 45 local charities, all of which interact with, and have a growing impact on, the work of multilateral organisations. As noted above in the case of Yemen, this aid particularly its development component ${ }^{7}-$ has been an important part of the UAE's projection of regional power, supporting particular political actors and opening investment opportunities for UAE commercial interests in the region (Hanieh 2013; Ulrichsen 2011; Young 2017). At the same time, foreign aid is also closely connected to the UAE's efforts to brand itself on the global stage - an attempt to achieve what Hertog has called "the accoutrements of 'good citizenship' and 'progressiveness' in the international arena through outward-oriented and costly activities” (Hertog 2017, 5). 
Importantly, however, alongside this quantitative growth in levels of foreign assistance, the UAE has also directly inserted itself in the logistics of humanitarian aid and its delivery. This is nowhere more clearly illustrated than Dubai International Humanitarian City (DIHC), which now constitutes the largest logistics hub for international humanitarian organisations in the world. DIHC was founded through a Dubai government directive in 2003, merging Dubai Aid City (DAC) and Dubai Humanitarian City (DHC). It has since seen major expansion following a relocation authorised by Dubai’s ruler, Sheikh Mohammed Bin Rashid Al Maktoum. The principal aim of this relocation was to anchor DIHC within the 'Dubai Logistics Corridor', a spatial agglomeration that encompasses Jebel Ali Port, Al Maktoum Airport, associated free zones for warehousing and commercial functions, and the residential city of Dubai South (a massive megaproject that is still under construction). ${ }^{8}$ Located centrally within this logistics space, DIHC hosts the main UN Humanitarian Response Depot (UNHRD, built in 2008), and the Global Logistics Service of the International Federation of Red Cross and Red Crescent Societies ${ }^{9}$. A further nine United Nations agencies and more than 80 NGOs and commercial entities are located in the zone as DIHC 'members'.

The international organisations located in DIHC coordinate humanitarian aid delivery across the globe. This includes, for example, facilitating emergency supplies to Syria and Afghanistan, flood recovery materials to Pakistan, airlifts to Bangladesh as part of the recent Rohingya crisis, and the delivery of aid to Haiti following the 2010 earthquake. Precisely because of DIHC's insertion in Dubai's wider logistics space, the function of DIHC is not restricted simply to coordination but incorporates the entire logistics chain - the import of goods through Jebel Ali Port or Al Maktoum airport, their transport to massive warehouses in DIHC, cataloguing and storage of goods, and their distribution to populations in need across 
the world.

Four unimposing corporate office buildings, a showroom of supplies, and a much larger industrial style depot make up the 'city', which stretches across 127,000 square metres. A security clearance is necessary to enter the buildings and there is extensive fencing and surveillance technology around the depot, giving the space the feel of a remote, disconnected industrial bunker. The main DIHC warehouse space - a large zone composed of multiple rows of interconnected steel sheds, cold rooms, and offices - is used for prepositioned emergency stocks including aid items like water purifiers, tents, blankets, vaccines and communication equipment. The depot's staff focuses on organising supplies and arranging shipments and customs clearances. In addition to managing supplies and coordinating between agencies, DIHC also acts as a base for fundraising activities facilitated in coordination with the Dubai government.

As with other free zones in the UAE, the Dubai government encourages international aid agencies to relocate to DIHC by providing space at no cost, support with visas, zero customs fees, and exemption from the new VAT introduced in the UAE in 2018. Such regulatory measures allow DIHC to operate as a networking space which, in the organisation's own words, "facilities, warehousing and close-knit network of partners in the private sector, local community, and government” (DIHC n.d.). DIHC'S upper and middle management are largely drawn from the wider Middle East and possess previous experience in the UN system. These personnel have the flexibility to work comfortably in Dubai (so long as they restrict criticism of the ruling family). At DIHC's helm is Chief Executive Officer Giuseppe Saba, who - in line with the overall growing prominence of logisticians in humanitarian agencies has a history of logistics work through UN agencies, and played an instrumental role in the 
founding of the United Nation's system of Humanitarian Response Depots, UNHRD. Alongside such management personnel, the manual labour of logistics is provided by a much larger group of mainly South-Asian migrant labour. These low paid workers are the hidden face of DIHC, maintaining warehouses and office spaces, building and operating transport infrastructure, and ensuring the 'efficiency' of the supply chain. The prominence of Dubai as a HL hub is contingent on this highly racialised labour regime, one that extends across the Emirate as a whole and underpins the development of all facets of the UAE logistics space.

At one level, the presence of DIHC in Dubai helps to reinforce the kinds of entanglements between military, commercial and humanitarian activities noted earlier. The huge volume of aid that moves in and out of DIHC warehouses - and its placement at the centre of a much wider 'logistics corridor' that connects Jebel Ali Port, Al Maktoum airport, and the associated processing and storage zones that surround DIHC - are seamlessly integrated with the growth of Dubai's wider logistics space. Importantly, and reflecting the global trends in HL noted earlier, DIHC activities are almost fully outsourced to private logistics firms. These include the aforementioned Agility, a member of DIHC, which established the Logistics Emergency Teams (LETs) initiative in 2005 to provide support for global humanitarian relief efforts as part of the UN Logistics Cluster. LETs was an outcome of the 2005 World Economic Forum, and saw Agility join with UPS, Maersk, and DP World in the first public-private HL partnership of its kind anywhere in the world - it is striking that two out of the four corporate partners in this global initiative are Dubai-based firms. In addition to firms such as Agility, a range of other commercial firms are members of DIHC, providing services such as armoured vehicles, the manufacture and provision of humanitarian supplies, training, and fundraising support. As one manager working for a large multilateral organisation noted in an interview: "we are very open to the private sector, we are happy to partner with corporations keen to 
show their corporate social responsibility and our door is always open” ${ }^{10}$ - indeed, more than one-fifth of DIHC members are commercial entities.

More broadly, DIHC’s activities are supported by the same tropes used to market Dubai as a global entrepot and headquarters for commercial logistics firms - namely, stability and security, easy proximity to millions of people across multiple continents, and an efficient, modernised and large-scale infrastructure. Simultaneously, the actual presence of DIHC in Dubai acts to reinforce and legitimate these marketing tropes; oft-repeated phrases such as Dubai is the "crossroads to the globe” (Mouawad 2017) or "gateway to the world” (Logistics Middle East 2014) depend critically on the repeated discursive confirmation of these notions. In this sense, DIHC constitutes a form of 'corporate branding' for both Dubai as "city corporation” (Kanna 2011) and its logistics sector. Logistical activities are ultimately fungible in nature - they do not distinguish between the commercial, humanitarian, or military goods that move through the logistics space - by placing Dubai at the centre of regional and global humanitarian support, DIHC helps to further project the city as an indispensible node in global commodity circulation.

These 'branding' effects also extend to Dubai's ruling Maktoum family. Indeed, members of the Maktoum family closely associate themselves with DIHC as part of an attempt to cultivate an image of modernising, generous, and liberal rule. Donations from the ruling family to DIHC have included land, physical infrastructure, and subsidised facilities. Indeed, throughout my visits to DIHC, many employees spoke of the 'generosity' of the ruling family and their commitment to humanitarian efforts - while some of this veneration could be simply performative, it nonetheless serves to highlight the discursive effects of such humanitarian spaces. Moreover, in a manner that echoes the particular gendering of humanitarian and 
charitable work across the Middle East, often personified in the prominent role of 'First Ladies' in this sector (Sukarieh 2015), Princess Haya Bint Al Hussein, a wife of Dubai's ruler, is the chairperson and an active public face for DIHC - meeting international stateguests and speaking in international fora on the humanitarian efforts of the organisation.

Of course, all of these features of DIHC and its role as a global platform for humanitarian logistics need to be situated within the broader regional expansion of the UAE's logistics space discussed above. The massive state-directed efforts aimed at building up and promoting Dubai as an international hub for humanitarian logistics is inseparable - both in practice and discourse - from the UAE's deep insertion in regional violence and the deliberate destruction of livelihoods and infrastructure in places such as Yemen. The UAE's projection of itself as ‘stable' and 'secure' fundamentally rests upon a perception of chaos and war elsewhere - a conceptual mirage that only functions if both sides of the couplet are kept as discrete, bounded, and un-entangled spaces. The lens of humanitarian logistics embodied in institutions such as DIHC helps to reveal the fallacy of such a view - exposing the conjoined nature of a single logistics space, centred upon the UAE, which binds militarism, humanitarianism, and commercial ambition across the wider region.

\section{Conclusion}

This article has demonstrated how the study of logistics chains helps elucidate the significant role of remote spaces in the "collusion of technologies of humanitarianism, human rights and humanitarian law with military and political powers” (Weizman 2011, 4). The transnational circuits of HL - increasingly superintended by states outside of the Global North and spatialised in zones that are constructed as 'stable' and 'secure' - allow us to capture the 
changing ways in which "the economy of violence is calculated and managed" (Weizman 2011 , 4) from a distance. The prominence of HL and professional logisticians in humanitarian practice - reflected in HL's codification as an academic ‘discipline’ and its status as a prerequisite for career advancement in the sector - is part of the more general intensification of logistics within supply-chain capitalism. As with logistics as a whole, the calculative logic and market-based efficiencies that underlie this new technocratic science serve to obfuscate its critical role in determining emergent forms of control and power.

These processes have had a profound impact on states such as the UAE. Building upon the historical advent of UAE logistics at the intersection of commercial and military power in the Gulf, the rise of HL has given the UAE significant leverage in expanding its own logistics space. The country's interlinked free zones, intermodal transportation hubs, and stratified labour markets have propelled the UAE's logistics space to the centre of the HL circuits that striate one of the most conflict-ridden regions in the world. Throughout this process, humanitarian, commercial and military logics play interchangeable and mutually-reinforcing roles - militaries and logistics firms serve as humanitarians, and humanitarianism helps to expand and grow military power and commercial reach. These dynamics are inherently crossborder in form and generative of a UAE logistics space that acts across multiple spatial scales. In this manner, a logistics lens helps us unpack the connections between the 'here' and 'there' of regional conflict zones, revealing the ways in which humanitarian intervention is productive of spaces that appear to be 'remote', but which, in actual fact, both perpetuate and benefit from conflict itself.

These trends hold important implications for thinking through future social, political and economic patterns in the Gulf. One of the striking features apparent in visits to the region is 
the rising prominence of an official discourse that links a sense of national identity and civic duty to the intersection of militarism and humanitarianism. This can be seen in the region's Arabic language press, which increasingly valorises military service by citizens, as well as a proliferation of new museums and cultural institutions that cast militarism as humanitarianism, and seek to project military and security apparatuses as a core feature of national unity. In Dubai, for example, the new Etihad Museum, which opened in January 2017, tells the story of the UAE's founding through multiple high-tech pavilions located next to the building where the 'union agreement' was signed between the different Emirates on December 17, 1971. The same year that the Etihad Museum opened was also designated by the UAE President, Khalifa bin Zayed Al Nahyan, as the 'Year of Giving', and as part of its commemoration an exhibition was held at the museum entitled 'Protectors of the Nation: Sacrifice and Giving', which highlighted the role of the UAE armed forces in global humanitarian efforts. According to the official press release that accompanied the exhibition, its goal was to demonstrate "the UAE's leading efforts in spreading tolerance, brotherhood and positive values that enhance community happiness across the world, as demonstrated by the participation of the UAE Armed Forces in many global relief campaigns and peacekeeping initiatives. Thanks to this strategy, the UAE has become a humanitarian role model for the international community” (Government of Dubai 2017). The museum's director explained "Our forces were there to help, to assist humanity: this shows the humanitarian side of the armed forces. We wanted people to see this” (Dennehy 2018). Exhibitions such as this appear to be largely oriented to the consumption of the UAE's citizen population; indeed, one of the striking features of the Etihad Museum is the almost complete absence of any mention of the country’s migrant worker population. 
This article has focused specifically on the UAE's logistics space, but it is important to acknowledge that other Gulf states are also seeking to expand their involvement in humanitarian logistics. Saudi Arabia, for example, established the King Salman Centre for Humanitarian Aid and Relief (KS Relief) in 2015, which, according to my interviewees in DIHC, was partly aimed at capturing some of the humanitarian work currently located in Dubai - my respondents were sceptical, however, that this attempt would be successful, given the greater restrictions on commercial activities and everyday lifestyles in the Kingdom. Likewise, Oman has embarked on a strategy of developing its maritime logistics sector through a number of Private-Public Partnerships with European port operators (Ziadah 2018), and this also includes attempts to attract aid agencies to the country’s new Logistics Parks. In this regard, the ICRC has established a logistics base in Oman's Salalah port and the World Food Programme has used Oman as an entry point for food items to Yemen (although this was largely co-ordinated through its headquarters in DIHC). As the development of a logistics space increasingly becomes an explicit measure of a country's development - a trend reflected in the growing use of 'logistics indexes' by multilateral organisations such as the World Bank - the competition between the various GCC states over multi-use logistics networks will likely increase.

Nonetheless, despite this heightened competitive environment, the UAE retains a significant advantage in that its logistics space has been uniquely shaped through the intersection of commercial, military, and humanitarian efforts. Placing a critical analysis of HL at the centre of our conceptual approaches to the new spaces of humanitarianism and humanitarian intervention is an essential part of understanding this predominance. Scholars need to insist that logistics spaces are just as inseparable from the ways that the militarism-humanitarianism nexus operates as they are in comprising the relations of power within 'normal' processes of 
capital circulation - the logistics lens helps reveal that all these activities are constituted in their unity and are expressive of new spatial geographies of control. In the contemporary international context of multiple, protracted, cross-border conflicts, the development of these logistics spaces will be a critical determinant of global power in the years to come.

\footnotetext{
${ }^{1}$ The cluster approach has been criticised. An evaluation found that although coordination among multilateral organisations improved, there was little involvement from local communities at the planning level (Steets et al., 2010: 55).
}

${ }^{2}$ For example, there are long-term partnerships like TNT and the World Food Programme's (WFP) 'Moving the World' initiative, WFP's first private sector partnership (UN World Food Programme 2012). Such collaborations are listed prominently in the various logistics companies' Corporate Social Responsibility (CSR) marketing materials.

${ }^{3}$ An important part of this control of labour is the Kafala system, which links employees' right to stay in the country directly to their employers (Buckley, Michelle 2014; Vora and Koch 2015; Dito, Mohammed 2014). More recently, strict biometric monitoring of residents was introduced through a mandatory Dubai ID and a population registry. Both military and commercial actors have tapped into this labour regime equally.

${ }^{4}$ This military intervention, 'asifat al-hazm (Decisive Storm), was launched by Saudi Arabia in 2015, in a coalition including Bahrain, Egypt, Jordan, Kuwait, Morocco, Qatar, Saudi Arabia, Sudan and United Arab Emirates. The operation was directed against Houthi fighters, ostensibly to restore legitimacy of exiled Yemeni president Abd Rabbuh Mansur Hadi.

${ }^{5}$ In part this is related to the UAE's desire to head off any potential competitors to its own port infrastructure, as well as grab a greater share of the expected increase in trade as a result of China's One Belt One Road initiative.

${ }^{6}$ This process is not without contradictions, and has disrupted regional alliances in the Horn of Africa itself (Cannon and Rossiter 2017). In March 2018, for example, DP World was forbidden from operation in Djibouti, when the government repossessed Doraleh Port, after losing a long-term legal dispute it had with the company over its concession contract there (Reuters 2018). Somalia also considered the UAE's overtures to Somaliland an infringement on its national sovereignty and prohibited the corporation from operating there, although it has no mechanism to enforce this in the autonomous territory.

${ }^{7}$ Humanitarian assistance only made up nine per cent of the UAE's total disbursements in 2016, highlighting the country's preference for bilateral assistance to governments. this still ranked is sixth internationally. 
${ }^{8}$ Dubai South is a major master planned expansion of Dubai to the south, dubbed the "flagship urban project" and a "city within a city". It sees Dubai sprawling further south, closer to the border with Abu Dhabi and away from its older centre around Port Rashid and the creek.

${ }^{9}$ The six UNHRD warehouses are located in: Accra (Ghana), Brindisi (Italy), Dubai (UAE), Subang (Malaysia), Panama City, (Panama) and Las Palmas (Spain) offering humanitarian logistics services to 64 member organisations (UNHRD, 2018).

${ }^{10}$ Interview with author, February 2017

\section{Bibliography}

Abrahamsen, Rita, and Anna Leander. 2015. Routledge Handbook of Private Security Studies. Routledge.

Al-Futtaim Logistics. n.d. 'Humanitarian and Military Logistics'. http://www.aflogistics.com/humanitarian-and-military-logistics.html.

Attewell, Wesley. 2018. "From Factory to Field": USAID and the Logistics of Foreign Aid in Soviet-Occupied Afghanistan'. Environment and Planning D: Society and Space 36 (4): 719-38.

Balcik, Burcu, and Benita M. Beamon. 2008. 'Performance Measurement in Humanitarian Relief Chains'. International Journal of Public Sector Management 21 (1): 4-25.

Bonacich, Edna, and Jake B. Wilson. 2008. Getting the Goods: Ports, Labor, and the Logistics Revolution. Ithaca, N.Y: Cornell University Press.

Bryan, Joe. 2015. 'War without End? Military Humanitarianism and the Limits of Biopolitical Approaches to Security in Central America and the Caribbean'. Political Geography 47 (July): 33-42.

Buckley, Michelle. 2013. 'Locating Neoliberalism in Dubai: Migrant Workers and Class Struggle in the Autocratic City'. Antipode 45 (2): 256-74.

Buckley, Michelle. 2014. 'Deconstructing the "Bachelor" Builder: Sexuality, Class and the Gendered Politics of Urbanization in Dubai'. In Transit States: Labour, Migration and Citizenship in the Gulf, edited by Khalaf, Abdulhadi, Hanieh, Adam, and AlShehabi, Omar. Pluto Press.

Calhoun, Craig, Adi Ophir, Ugo Mattei, Chowra Makaremi, Vanessa Pupavac, Peter Redfield, Paula Vásquez Lezama, et al. 2010. Contemporary States of Emergency: The Politics of Military and Humanitarian Interventions. Edited by Didier Fassin and Mariella Pandolfi. 1 edition. New York : Cambridge, Mass: Zone Books.

Cannon, Brendon, and Ash Rossiter. 2017. 'Ethiopia, Berbera Port and the Shifting Balance of Power in the Horn of Africa'. SSRN Scholarly Paper ID 3107475. Rochester, NY: Social Science Research Network. https://papers.ssrn.com/abstract=3107475.

Chandler, David G. 2001. 'The Road to Military Humanitarianism: How the Human Rights NGOs Shaped A New Humanitarian Agenda'. Human Rights Quarterly 23 (3): 678700.

Chandrasekaran, Rajiv. 2014. 'In the UAE, the United States Has a Quiet, Potent Ally Nicknamed “Little Sparta”'. Washington Post. 9 November 2014. 
https://www.washingtonpost.com/world/national-security/in-the-uae-theunited-states-has-a-quiet-potent-ally-nicknamed-littlesparta/2014/11/08/3fc6a50c-643a-11e4-836c-83bc4f26eb67_story.html.

Chua, Charmaine. 2018. 'Containing the Ship of State: Managing Mobility in an Age of Logistics', July. http://conservancy.umn.edu/handle/11299/200214.

Chung, Patrick. 2019. 'From Korea to Vietnam Local Labour, Multinational Capital, and the Evolution of US Military Logistics, 1950-97'. Radical History Review 2019 (133): 31-55.

Cowen, Deborah. 2014. The Deadly Life of Logistics: Mapping Violence in Global Trade. Minneapolis: University of Minnesota Press.

Danyluk, Martin. 2017. 'Capital's Logistical Fix: Accumulation, Globalization, and the Survival of Capitalism'. Environment and Planning D: Society and Space, April, 0263775817703663.

Davidson, Christopher M. 2008. Dubai: The Vulnerability of Success. London: Hurst.

Davis, Mike. 2006. 'Fear and Money in Dubai'. New Left Review 41: 47-68.

Dennehy, John. 2018. 'Humanitarian Work of UAE Armed Forces in Focus at Etihad Museum'. The National. 27 January 2018.

https://www.thenational.ae/uae/heritage/humanitarian-work-of-uae-armedforces-in-focus-at-etihad-museum-1.699203.

DIHC. n.d. 'International Humanitarian City'. International Humanitarian City. Accessed 18 August 2018. http://www.ihc.ae/.

Dito, Mohammed. 2014. 'Kafala: Foundations of Migrant Exclusion in GCC Labour Markets'. In Transit States: Labour, Migration and Citizenship in the Gulf, edited by Abdulhadi, Khalaf, AlShehabi, Omar, and Hanieh, Adam, 79-100. Pluto Press.

Duffield, Mark. 2001. 'Governing the Borderlands: Decoding the Power of Aid'. Disasters 25 (4): 308-20.

——_. 2012. 'Challenging Environments: Danger, Resilience and the Aid Industry'. Security Dialogue 43 (5): 475-92.

- - - 2016. 'The Resilience of the Ruins: Towards a Critique of Digital Humanitarianism'. Resilience 4 (3): 147-65.

Elsheshtawy, Yasser. 2010. Dubai: Behind an Urban Spectacle. Planning, History and Environment Series. New York: Routledge.

Fabbe-Costes, Nathalie, Christine Roussat, and Marianne Jahre. 2008. 'Supply Chain Integration: The Role of Logistics Service Providers'. International Journal of Productivity and Performance Management 58 (1): 71-91.

Fassin, Didier. 2011. Humanitarian Reason: A Moral History of the Present. University of California Press.

Fassin, Didier, and Mariella Pandolfi. n.d. Contemporary States of Emergency. The Politics of Military and Humanitarian Interventions. Zone Books.

Fox-Hodess, Katy. 2017. '(Re-)Locating the Local and National in the Global: Multi-Scalar Political Alignment in Transnational European Dockworker Union Campaigns'. British Journal of Industrial Relations 55 (3): 626-47.

Government of Dubai. 2017. 'Protectors of the Nation: Sacrifice and Giving Exhibition Is Open for the Public at EM'. 13 December 2017. https://dubaiculture.gov.ae/en/Media/Press-Releases/Pages/-Protectors-ofthe-Nation-Sacrifice-and-Giving-Exhibition-is-Open-for-the-Public-at-EM.aspx.

Graham, Stephen. 2009. 'Cities as Battlespace: The New Military Urbanism'. City 13 (4): 383-402. 
Gray, Richard, and Richard Oloruntoba. 2009. 'Customer Service in Emergency Relief Chains'. International Journal of Physical Distribution \& Logistics Management 39 (6): 486-505.

Gregory, Derek. 2011. 'The Everywhere War'. The Geographical Journal 177 (3): 238-50. Hanieh, Adam. 2013. Lineages of Revolt: Issues of Contemporary Capitalism in the Middle East. Chicago, Illinois: Haymarket Books.

Heard-Bey, Frauke. 1982. From Trucial States to United Arab Emirates: A Society in Transition. London; New York: Longman.

Hertog, Steffen. 2017. 'A Quest for Significance: Gulf Oil Monarchies' International “soft Power" Strategies and Their Local Urban Dimensions'. Monograph. 2017. http://www.lse.ac.uk/middleEastCentre/kuwait/home.aspx.

Jones, T. C. 2012. 'America, Oil, and War in the Middle East'. Journal of American History 99 (1): 208-18.

Kanna, Ahmed. 2011. Dubai, the City as Corporation. Minneapolis: University of Minnesota Press.

Kanngieser, Anja. 2013. 'Tracking and Tracing: Geographies of Logistical Governance and Labouring Bodies'. Environment and Planning D: Society and Space 31 (4):

Katzman, Kenneth. 2013. 'The United Arab Emirates (UAE): Issues for U.S. Policy'. CRSRS21852. Library of Congress Washington DC Congressional Research Service, Library of Congress Washington DC, Congressional Research Service.

Khalili, Laleh. 2012. Time in the Shadows: Confinement in Counterinsurgencies. Stanford University Press.

Kovács, Gyöngyi, and Karen M. Spens. 2011. 'Trends and Developments in Humanitarian Logistics - a Gap Analysis'. International Journal of Physical Distribution \& Logistics Management 41 (1): 32-45.

Levinson, Marc. 2008. The Box: How the Shipping Container Made the World Smaller and the World Economy Bigger. 9. print., and 1. paperback print. Princeton, NJ: Princeton Univ. Press.

Logistics Middle East. 2014. 'Jafza Highlights Dubai as Gateway to the World for Asia'. Logistics Middle East. 12 June 2014. https://www.logisticsmiddleeast.com/article-9956-jafza-highlights-dubai-asgateway-to-the-world-for-asia.

Manek, Nizar. 2018. 'U.A.E. Military Base in Breakaway Somaliland to Open by June'. Bloomberg, 6 November 2018. https://www.bloomberg.com/news/articles/2018-11-06/u-a-e-military-basein-breakaway-somaliland-seen-open-by-june.

McCormack, Killian, and Emily Gilbert. 2018. 'Spaces at the Intersections of Militarism and Humanitarianism'. Critical Military Studies 4 (2): 97-101.

Mezzadra, Sandro, and Brett Neilson. 2015. 'Operations of Capital'. South Atlantic Quarterly 114 (1): 1-9. https://doi.org/10.1215/00382876-2831246.

Molavi, Afshin. 2005. 'Dubai Rising'. Brown Journal of World Affairs 12: 103.

Moore, Adam. 2017. 'US Military Logistics Outsourcing and the Everywhere of War'. Territory, Politics, Governance 5 (1): 5-27. https://doi.org/10.1080/21622671.2016.1160837.

Mouawad, Jad. 2017. 'Dubai, Once a Humble Refueling Stop, Is Crossroad to the Globe'. The New York Times, 20 December 2017, sec. Business. https://www.nytimes.com/2014/06/19/business/international/once-ahumble-refueling-stop-dubai-is-crossroad-to-the-globe.html. 
Neilson, Brett. 2012. 'Five Theses on Understanding Logistics as Power'. Distinktion: Journal of Social Theory 13 (3): 322-39.

Ramos, Stephen J. 2010. Dubai Amplified: The Engineering of a Port Geography. Design and the Built Environment Series. Farnham, Surrey, England ; Burlington, VT: Ashgate Pub.

Reuters. 2017. 'Kuwait Logistics Firm Agility Says Settles U.S. Criminal Case', 24 May 2017. https://www.reuters.com/article/us-pws-settlement/kuwait-logisticsfirm-agility-settles-u-s-criminal-case-idUSKBN18K0U1.

—- - 2018. 'DP World Accuses Djibouti of Illegal Seizure of Dorelah Port', 22 February 2018. https://www.reuters.com/article/djibouti-ports-dp-world/dp-worldaccuses-djibouti-of-illegal-seizure-of-dorelah-port-idUSL8N1QC7QY.

Sekula, Allan, and Noël Burch. 2011. 'The Forgotten Space'. New Left Review, II, , no. 69 (June): 78-79.

Seshadri, Kalpana Rahita. 2008. 'When Home Is a CampGlobal Sovereignty, Biopolitics, and Internally Displaced Persons'. Social Text 26 (1 (94)): 29-58.

Smirl, Lisa. 2015. Spaces of Aid: How Cars, Compounds and Hotels Shape Humanitarianism. Zed Books Ltd.

Tomasini, Rolando M., and Luk N. Van Wassenhove. 2009. 'From Preparedness to Partnerships: Case Study Research on Humanitarian Logistics'. International Transactions in Operational Research 16 (5): 549-59.

Toscano, Alberto. 2014. 'Lineaments of the Logistical State'. Viewpoint Magazine (blog). 2014. https://viewpointmag.com/2014/09/28/lineaments-of-the-logisticalstate/.

Tsing, Anna. 2009. 'Supply Chains and the Human Condition'. Rethinking Marxism 21 (2): 148-76.

Ulrichsen, Kristian Coates. 2011. 'Repositioning the GCC States in the Changing Global Order'. Journal of Arabian Studies 1 (2): 231-47. https://doi.org/10.1080/21534764.2011.630894.

UN World Food Programme. 2012. 'TNT and WFP Celebrate 10 Years Of Partnership'. 11 December 2012. https://www.wfp.org/stories/tnt-and-wfp-celebrate-10-yearanniversary-partnership.

United Arab Emirates Ministry of Foreign Affairs \& International Cooperation. 2017. 'UAE Foreign Aid 2016'. https://www.mofa.gov.ae/SiteCollectionDocuments/UAEFAR/

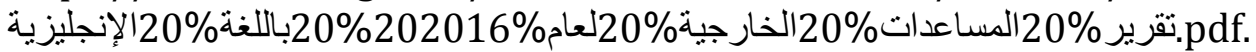

Van der Laan, E.a., M.p. De Brito, and D.a. Vergunst. 2009. 'Performance Measurement in Humanitarian Supply Chains'. International Journal of Risk Assessment and Management 13 (1): 22-45.

Van Wassenhove, L. N. 2006. 'Humanitarian Aid Logistics: Supply Chain Management in High Gear'. The Journal of the Operational Research Society 57 (5): 475-89.

Vora, Neha, and Natalie Koch. 2015. 'Everyday Inclusions: Rethinking Ethnocracy, Kafala, and Belonging in the Arabian Peninsula'. Studies in Ethnicity and Nationalism 15 (Acco3): 540-52.

Weizman, Eyal. 2011. The Least of All Possible Evils: Humanitarian Violence from Arendt to Gaza. Verso Books.

Whiting, Michael C., and Beatriz E. Ayala-Öström. 2009. 'Advocacy to Promote Logistics in Humanitarian Aid'. Management Research News 32 (11): 1081-89. 
Young, Karen E. 2017. 'A New Politics of GCC Economic Statecraft: The Case of UAE Aid and Financial Intervention in Egypt'. Journal of Arabian Studies 7 (1): 113-36.

Zahlan, Rosemarie Said. 2016. The Origins of the United Arab Emirates: A Political and Social History of the Trucial States. Routledge.

Ziadah, Rafeef. 2017. 'Constructing a Logistics Space: Perspectives from the Gulf Cooperation Council'. Environment and Planning D: Society and Space, December, . 2018. 'Transport Infrastructure and Logistics in the Making of Dubai Inc.' International Journal of Urban and Regional Research 42 (2): 182-97. 